\title{
THE BRACHYURA (CRUSTACEA: DECAPODA) COLLECTED BY THE GEDIP PROJECT BETWEEN TORRES, RIO GRANDE DO SUL (BRAZIL) AND MALDONADO (URUGUAY)
}

\author{
GUSTAVO AUGUSTO S. DE MELO \\ Museu de Zoologia da Universidade de São Paulo, Av. Nazareth, 481, Ipiranga -04263-000 São Paulo. Brasil. gasmelo@usp.br.
}

\section{ABSTRACT}

An agreement between the Executive Group for Industrial Fisheries Development (GEDIP) and the Oceanographic Institute of the University of São Paulo (IOUSP), gave rise to an extensive project. This extensive project was the GEDIP Project, carried out off the coast of the state of Rio Grande do Sul, but with several stations as far south as Maldonado in Uruguay. Of the 442 stations visited by the R/V "Prof. W. Besnard" during the project, brachyuran crabs occurred at 219 and 57 species were collected, members of 45 genera and 23 families. For each species, the geographical distribution, habitat, and a list of the stations where it occurred are provided. In addition, a table listing oceanographic data and the species occurring at each station is given.

KEY WORDS: Brachyura, southern Brazil, uruguayan waters, oceanographic data.

\section{RESUMO}

Os Brachyura (Crustacea: Decapoda) coletados pelo projeto GEDIP entre Torres, Rio Grande do Sul (Brasil) e Maldonado (Uruguai)

Um convênio entre o Grupo Executivo do Desenvolvimento da Indústria da Pesca (GEDIP) e o Instituto Oceanográfico da Universidade de São Paulo (IOUSP), deu origem a um amplo projeto denominado Projeto GEDIP, a ser desenvolvido na costa do Rio Grande do Sul, mas com várias estações até Maldonado, no Uruguai. Do total de 442 estações efetuadas pelo N.Oc. "Prof. W. Besnard" durante o projeto, em 219 ocorreram Brachyura, sendo coletadas 57 espécies, distribuídas em 45 gêneros e 23 famílias. Para cada espécie são fornecidas informações sobre: distribuição geográfica, habitat e lista das estações em que ocorreram. É fornecida, também, uma tabela com os dados oceanográficos de cada estação e com as espécies que ocorreram em cada uma delas.

PALAVRAS CHAVE: Brachyura, Sul do Brasil, costa uruguaia, dados oceanográficos.

\section{INTRODUCTION}

The Executive Group for Industrial Fisheries Development (GEDIP) of the state of Rio Grande do Sul, and the Oceanographic Institute of the University of São Paulo (IOUSP) united in an extensive research project.

The data initially published from the study characterized the regional ecological aspects: temperature, salinity, bottom types, and ocean circulation (Luedmann 1971; Magliocca 1971; Miranda 1971; Miranda et al. 1973). However, the biodiversity of the region was reported only for certain groups and in brief reports about the project, by specialists of the USP Oceanographic Institute, such as: Amphipoda (Wakabara 1973), Isopoda (Moreira,1973), commercially valuable shrimps (Iwai 1973), Zooplankton (Navas-Pereira 1973), Polychaete annelids (Nonato 1973), Porifera (Ribeiro et al. 1973), Echinodermata (Tommasi et al. 1973b), Pelecypoda and Gastropoda (Tommasi \& Rios 1973) and fishes (Vazzoler et al. 1973; Sadowsky 1973; Benvegnú 1973; Vazzoler 1975).

The GEDIP Project continued from 1968 to 1972 , with a total of 442 stations sampled, and was divided into two phases. The first phase (GEDIP I), with 6 cruises and 226 stations, took place between 24 April 1968 and 20 March 1969, with collections between Torres, Rio Grande do Sul (29ำ 21'S: 49응

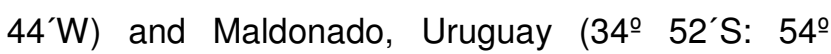
$55^{\prime} \mathrm{W}$ ), and a few stations beyond this limit. The second phase (GEDIP II), with 4 cruises and 216 stations, took place during the year 1972 (from 16 January to 3 November), when collections were

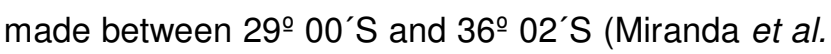
1973; Furtado 1973), with 54 stations visited off the Uruguayan coast.

The objective of this work was generating biotic and abiotic data, in addition to studying the biodiversity of the southern coast of Brazil.

\section{MATERIAL AND METHODS}

In general, the stations were limited to the continental shelf, although some extended to the upper slope (Melo-Filho \& Melo 2001). The ship used in the collections was the R/V "Prof. W. Besnard." The material of Brachyura obtained during the project was deposited in the Carcinological Collection of the Museum of Zoology of the University of São Paulo (MZUSP). 
For each species, the following data are reported: geographical distribution, habitat and material examined. Information on the collection stations (coordinates, date, depth, temperature, salinity and the species that occurred at each station) is given in Table I. Information on the gear used in the collections was provided by Tommasi et al. (1973a), and on the bottom types by Furtado (1973).

The classification of the species, genera and families is based on the work recently published of $\mathrm{Ng}$ et al. (2008).

\section{RESULTS}

The Brachyura was the most species-rich group of benthic macro-crustaceans collected on the continental shelf of Rio Grande do Sul during the project, principally between the 50 and 100 meter isobaths (Tommasi et al. 1973a). Of the total of 442 stations visited during the entire project, members of the Brachyura occurred at $219(49.5 \%)$, at 134 stations of the first phase and 85 stations of the second. In total, 57 species of Brachyura, members of 45 genera and 23 families were collected. The stations with the most species were 1646 (9 species), and 569 and 1883 (7 species each). The species collected at the most stations were: Libinia spinosa (69 stations), Chasmocarcinus typicus and Hepatus pudibundus (27 stations).

\title{
TAXONOMIC ACCOUNT
}

\author{
Superfamily Dromioidea De Haan, 1833
}

\section{FAMILY DROMIIDAE De Haan, 1833}

Moreiradromia antillensis (Stimpson, 1858)

Distribution: Western Atlantic - North Carolina, Bermuda, Florida, Gulf of Mexico, Antilles, Venezuela, Guiana, Suriname, French Guiana and Brazil (from
Amapá to Rio Grande do Sul). Central Atlantic - Saint Helena Island.

Habitat: Hard substrates such as corals, broken shells, and rocks. Intertidal to $330 \mathrm{~m}$. Generally covers the carapace with sponges or ascidians.

Material examined: Stations 313, 458, 552.

\section{Superfamily Homoloidea De Haan, 1839}

\section{FAMILY HOMOLIDAE De Haan, 1839}

Homola minima Guinot \& Richer de Forges, 1995

Distribution: Western Atlantic - From Virginia to Florida, Gulf of Mexico, Central America, Antilles, northern South America, and Brazil (from Rio de Janeiro to Rio Grande do Sul).

Habitat: Sand, shell, and coral bottoms; occasionally on muddy substrates. Occurs at depths of 55 to $690 \mathrm{~m}$.

Material examined: Stations 378, 396, 569, 1872, 1873.
FAMILY LATREILLIIDAE Stimpson, 1858

Latreillia williamsi Melo, 1990

Distribution: Western Atlantic - Brazil (from Rio de Janeiro to Rio Grande do Sul).

Habitat: Usually on sand, gravel, mud or shell substrates. Depths from 130 to $290 \mathrm{~m}$.

Material examined: Stations 367, 368, 396 (holotypeMZUSP-3295), 401, 411, 412, 438, 539, 541, 547, 554 , 568, 569, 576, 1646, 1648, 1656, 1740, 1742, $1856,1883$. 
FAMILY CYCLODORIPPIDAE Ortmann, 1892

Deilocerus perpusillus (Rathbun, 1901)

Distribution: Western Atlantic - North Carolina to Georgia, Bahamas, Gulf of Mexico, Antilles, and Brazil (from Amapá to Rio Grande do Sul).

Habitat: On gravel, sand and mud substrates. At depths ranging from 30 to 180 meters. Sometimes carry hydrozoans on the carapace.

Material examined: Station 1646.
FAMILY CYMONOMIDAE Bouvier, 1898

Cymonomus quadratus A. Milne-Edwards, 1880

Distribution: Western Atlantic - Florida, Gulf of Mexico, Antilles and Brazil (Amapá and from Rio de Janeiro to Rio Grande do Sul).

Habitat: Sand and mud bottoms. From 190 to 930 meters. Off the Brazilian coast, between 200 and $600 \mathrm{~m}$. Material examined: Station 1646.

Superfamily Calappoidea De Haan, 1833

FAMILY CALAPPIDAE De Haan, 1833

Acanthocarpus alexandri Stimpson, 1871

Distribution: Western Atlantic - Massachusetts, North Carolina to Florida, Gulf of Mexico, Antilles and Brazil (from Rio de Janeiro to Rio Grande do Sul).
Habitat: Principally on sand and mud bottoms. Between 70 and $480 \mathrm{~m}$.

Material examined: Stations $315,465,473,561,1664$, 1680, 1691, 1696, 1697, 1718, 1758, 1872, 1881, 1909.

Superfamily Aethroidea Dana, 1851

FAMILY AETHRIDAE Dana, 1851

Hepatus pudibundus (Herbst, 1785)

Distribution: Western Atlantic - Georgia, Gulf of Mexico, Antilles, Venezuela, Guianas and Brazil (from Amapá to Rio Grande do Sul). Eastern Atlantic From Guinea to South Africa.

Habitat: Principally mud, sand and broken-shell bottoms. Shallow waters to $160 \mathrm{~m}$. Sometimes carries anemones and barnacles on its carapace.

Material examined: Stations 364, 395, 396, 397, 402403, 407, 409, 471, 538, 544, 550, 564, 573, 577, $579,583,590,592,1643,1660,1688,1699,1725$, 1732, 1851, 1918.
Osachila antillensis Rathbun, 1916

Distribution: Western Atlantic - Bermuda, Gulf of Mexico, Antilles and Brazil (from Amapá to Rio Grande do Sul).

Habitat: From 80 to $300 \mathrm{~m}$. Sand, shell and coral bottoms and hard substrates.

Material examined: Station 1883.

Osachila tuberosa Stimpson, 1871

Distribution: Western Atlantic - North Carolina, Florida, Gulf of Mexico, Antilles, Venezuela and Brazil (from Rio de Janeiro to Rio Grande do Sul).

Habitat: Coral and shell bottoms, occasionally on sand. Between 40 and 90 m., most common at depths of about $40 \mathrm{~m}$.

Material examined: Stations 411, 569, 1646, 1740. 
FAMILY LEUCOSIIDAE Samouelle, 1819

Myropsis quinquespinosa Stimpson, 1871

Distribution: Western Atlantic - Massachusetts, North Carolina, Florida, Gulf of Mexico, Antilles, Colombia, Venezuela, Suriname, Brazil (from Rio de Janeiro to Rio Grande do Sul), Uruguay and Argentina.

Habitat: Mud, sand and shell bottoms. Between 90 and 330 meters.

Material examined: Stations $330,374,460,1656$, 1680, 1758, 1848, 1855, 1856, 1872, 1891, 1907.
Persephona mediterranea (Herbst, 1794)

Distribution: Western Atlantic - New Jersey, Carolinas, Florida, Gulf of Mexico, Antilles, Venezuela, Suriname, French Guiana, Brazil (from Amapá to Rio Grande do Sul) and Uruguay.

Habitat: Sand, shell, and coral bottoms. Intertidal to $60 \mathrm{~m}$.

Material examined: Stations 315, 383, 397, 402, 403, $460,464,470,538,544,557,579,582,592,1688$, 1699, 1715.

Superfamily Majoidea Samouelle, 1819

FAMILY INACHIDAE MacLeay, 1838

Podochela atlantica (Coelho, 1997)

Distribution: Western Atlantic - Brazil (Santa Catarina and Rio Grande do Sul) and Uruguay.

Habitat: Between 130 and 160 m. On sand, mud-sand and organogenic bottoms.

Material examined: Stations 547 (paratype - MZUSP3522), 554 (holotype MZUSP-3533) 576 (paratype MZUSP-5975).

Anomalothir furcillatus (Stimpson, 1871)

Distribution: Western Atlantic - North Carolina, Florida, Gulf of Mexico, Antilles and Brazil (Rio Grande do Sul).

Habitat: Mud, sand, shell, rock and coral bottoms. Between 50 and 690 meters. Most common at depths greater than 180 meters.

Material examined: Stations 437, 458, 1856.

\section{Eurypodius latreillii Guérin, 1825}

Distribution: Western Atlantic - Brazil (from Rio de Janeiro to Rio Grande do Sul) and Argentina (including Patagonia), Falkland Islands and the Straits of Magellan. Eastern Pacific - Peru and Chile.

Habitat: From shallow water to 90 meters, dock pilings and rock bottoms. Individuals may carry algae, sponges and bryozoans. Some specimens were collected at depths over 100 meters.

Material examined: Station 1873.

\section{Stenorhynchus seticornis (Herbst, 1788)}

Distribution: Western Atlantic - Bermuda, North Carolina, Florida, Gulf of Mexico, Antilles, Colombia, Venezuela, Guianas, Brazil (from Amapá to Rio Grande do Sul), Uruguay and Argentina.

Habitat: Calcareous-algae, corals, rock, shell and sand bottoms. Occurs together with sponges. Movies slowly, in hops. Does not camouflage itself; is sometimes parasitized by sacculinids. From the intertidal zone to great depths.

Material examined: Station 586. 
FAMILY INACHOIDIDAE Dana, 1851

Collodes rostratus A. Milne-Edwards, 1879

Distribution: Western Atlantic - Brazil (from Rio de Janeiro to Rio Grande do Sul), Uruguay and Argentina (including Patagonia).

Habitat: Preferentially on sand, shell, and mud bottoms. Between 10 and 70 meters.

Material examined: Stations 405, 409, 455, 1656, 1868.

\section{Euprognatha rastellifera Stimpson, 1871}

Distribution: Western Atlantic - Massachusetts to Florida, Gulf of Mexico, Antilles, Guianas, Brazil (from Amapá to Rio Grande do Sul) and Uruguay.

Habitat: Sand, coral, and shell bottoms. Shallow waters to considerable depths $(710 \mathrm{~m})$.

Material examined: Stations 465, 1646, 1856, 1883.

Leurocyclus tuberculosus (H. Milne Edwards \& Lucas, 1842)

Distribution: Western Atlantic - Brazil (from Rio de Janeiro to Rio Grande do Sul), Uruguay and Argentina (including Patagonia). Eastern Pacific - Chile.

Habitat: Preferentially on sand, shell, and mud bottoms. Between 10 and $70 \mathrm{~m}$.

Material examined: Stations $275,277,279,280,281$, 289, 291, 325, 328, 406, 410, 413, 434, 460, 468, $471,538,543,566,571,582,590,592,1644,1646$, 1659, 1688, 1745, 1868, 1917, 1923.

FAMILY MAJIDAE Samouelle, 1819

Microphrys bicornutus (Latreille, 1825)

Distribution: Western Atlantic - North Carolina to southern Florida, Bermuda, Gulf of Mexico, Antilles, Central America, Venezuela and Brazil (Fernando de Noronha, and from Maranhão to Rio Grande do Sul).

Habitat: Very common on coral reefs and in almost all shallow marine habitats. Almost always covered with anemones, algae or sponges.

Material examined: Station 550.
Mithrax besnardi Melo, 1990

Distribution: Western Atlantic - Brazil (Rio Grande do Sul).

Habitat: The only existing specimens were on a mud bottom and a depth of 2,100 meters.

Material examined: Station 1872 (Holotype -MZUSP4565) (Paratypes - MZUSP-6242 and MZUSP-7519)..

Stenocionops furcatus (Olivier, 1791)

Distribution: Western Atlantic - Georgia, Florida, Gulf of Mexico, Antilles, Colombia and Brazil (from Ceará to Rio Grande do Sul).

Habitat: Sand, rock, mud and coral bottoms, and on wharf pilings. Transports different species of anemones and sponges on its carapace and appendages. From intertidal zone to $180 \mathrm{~m}$.

Material examined: Stations 280, 405, 412, 449, 554.

Stenocionops spinosissimus (De Saussure, 1857)

Distribution: Western Atlantic - North Carolina, Florida, Gulf of Mexico, Antilles and Brazil (Fernando de Noronha and from Rio Grande do Norte to Rio Grande do Sul).

Habitat: This species occurs at depths of 40 to $480 \mathrm{~m}$. On mud and sand bottoms.

Material examined: Station 1856.

FAMILY EPIALTIDAE MacLeay, 1838

Apiomithrax violaceus (A. Milne-Edwards, 1868)

Distribution: Western Atlantic - Brazil (from Paraiba to Rio Grande do Sul). Eastern Atlantic - Cape Verde islands and from Cabo Branco to Angola. Mid-Atlantic - Ascension Island.

Habitat: Sand and mud bottoms. From shallow waters to $50 \mathrm{~m}$.

Material examined: Station 586.

Lepteces ornatus Rathbun, 1893

Distribution: Western Atlantic - Yucatan, Mexico and Brazil (Rio Grande do Sul).

Habitat: Between 150 to $250 \mathrm{~m}$.

Material examined: Station 1881. 
Libidoclaea granaria H. Milne Edwards \& Lucas, 1842

Distribution: Western Atlantic - Brazil (Rio Grande do Sul), and Argentina (including Patagonia). Eastern Pacific - Chile.

Habitat: This species occurs at depths greater than 70 meters and is not collected in coastal waters.

Material examined: Stations 1675, 1918.

Libinia ferreirae Brito Capello, 1871

Distribution: Western Atlantic - Venezuela and Brazil (from Pará to Rio Grande do Sul).

Habitat: Preferentially on mud bottoms. Intertidal to $35 \mathrm{~m}$.

Material examined: Station 1917.

Libinia spinosa $\mathrm{H}$. Milne Edwards, 1834

Distribution: Western Atlantic - Brazil (from Espírito Santo to Rio Grande do Sul), Uruguay and Argentina.

Habitat: Generally on mud bottoms. From shallow waters to $170 \mathrm{~m}$.

Material examined: Stations: 275, 282, 289, 291, 299, $310,324,364,365,371,397,403,405-409,414,425$,
430, 431, 441, 447, 452, 455, 460, 463, 467, 468, $470,471,543,549,550,558,564,577,582,583$, $586,1643,1644,1651,1652,1660,1662,1668$, $1670,1675,1679,1686-1688,1698,1699,1724$, 1867, 1868, 1876, 1893, 1916, 1923, 1925, 1926, 1931, 1932, 1937, 1938, 1940.

Pelia rotunda A. Milne-Edwards, 1875

Distribution: Western Atlantic - Brazil (from Pará to Rio Grande do Sul), Uruguay and Argentina.

Habitat: Sand and calcareous-algae bottoms. Intertidal to $190 \mathrm{~m}$.

Material examined: Station 1893.

Rochinia gracilipes A. Milne-Edwards, 1875

Distribution: Western Atlantic - Brazil (from Rio de Janeiro to Rio Grande do Sul), Uruguay, Argentina and Antarctica.

Habitat: Sand, gravel and shell bottoms. Sometimes among submersed vegetation. Between 15 and $175 \mathrm{~m}$.

Material examined: Stations 405, 1868, 1874, 1884.

\section{Superfamily Parthenopoidea MacLeay, 1838}

\section{FAMILY PARTHENOPIDAE MacLeay, 1838}

Heterocrypta lapidea Rathbun, 1901

Distribution: Western Atlantic - Antilles and Brazil (from Pará to Rio Grande do Sul).

Habitat: Sand, mud and shell bottoms. Intertidal to $180 \mathrm{~m}$.

Material examined: Stations 449, 1748, 1756.

\section{Mesorhoea sexspinosa Stimpson, 1871}

Distribution: Western Atlantic - North Carolina, Florida, Gulf of Mexico, Antilles and Brazil (from Pará to Rio Grande do Sul).

Habitat: Mainly on sand and shell bottoms. Intertidal to $100 \mathrm{~m}$.

Material examined: Stations 417, 425.
Spinolambrus fraterculus (Stimpson, 1871)

Distribution: Western Atlantic - From North Carolina to Florida, Gulf of Mexico, Antilles, Suriname, Brazil (from Amapá to Rio Grande do Sul), Uruguay and Argentina.

Habitat: Sand, shell, gravel, rock and coral bottoms. Shallow waters to $200 \mathrm{~m}$.

Material examined: Stations 411, 579, 1646, 1883.

\section{Spinolambrus pourtalesii (Stimpson, 1871)}

Distribution: Western Atlantic - From Massachusetts to southern Florida, Gulf of Mexico, Antilles and Brazil (from Amapá to Rio Grande do Sul).

Habitat: Mud, sand, shell and gravel bottoms. Between 20 and $350 \mathrm{~m}$.

Material examined: Stations 279, 412, 444, 568, 569, $588,1662$. 
FAMILY ATELECYCLIDAE Ortmann, 1893

Peltarion spinulosum (White, 1843)

Distribution: Western Atlantic - Brazil (Rio Grande do Sul), Uruguay, and Argentina (including Patagonia).

Eastern Pacific - Chile.
Habitat: Sand and mud bottoms. Found at shallow depths, but reaches $300 \mathrm{~m}$.

Material examined: Stations 405, 1917-1919, 1921.

Superfamily Bellioidea Dana, 1852

FAMILY BELLIIDAE Dana, 1852

Bellia picta $\mathrm{H}$. Milne Edwards, 1848

Distribution: Western Atlantic - Brazil (Rio Grande do Sul). Eastern Pacific - Peru and Chile.

Habitat: A very rare species. From study of its anatomy, some workers have concluded that it is a burrower and filter-feeder. The single specimen was collected at $116 \mathrm{~m}$.

Material examined: Station 1730.
Corystoides chilensis Lucas, 1844

Distribution: Western Atlantic - Brazil (from Rio de Janeiro to Rio Grande do Sul), Uruguay and Argentina (including Patagonia). Eastern Pacific - Chile.

Habitat: Mud and sand bottoms. Lives almost completely buried in the substrate. At depths from 5 to $30 \mathrm{~m}$.

Material examined: Stations 407, 409, 1644.

\section{Superfamily Portunoidea Rafinesque, 1815}

\section{FAMILY PORTUNIDAE Rafinesque, 1815}

Arenaeus cribrarius (Lamarck, 1818)

Distribution: Western Atlantic - Massachusetts to North Carolina, Bermuda, Florida, Gulf of Mexico, Antilles, Colombia, Venezuela, Brazil (from Ceará to Rio Grande do Sul), Uruguay and Argentina.

Habitat: Well adapted to live in beach sand. Found rarely in estuaries or inland ponds. Juveniles of this species were collected at 6-10 m., on sand and mudsand sediments (Scelzo 2001).

Material examined: Stations 555, 565, 1671, 1725, 1853.

Callinectes danae Smith, 1869

Distribution: Western Atlantic - North Carolina, Bermuda, Florida, Gulf of Mexico, Antilles, Colombia, Venezuela, and Brazil (from Pará to Rio Grande do Sul).
Habitat: Occurs in brackish to hypersaline waters, in mangroves and muddy estuaries. Also on sandy beaches and in the open sea. Intertidal to $75 \mathrm{~m}$.

Material examined: Station 416.

\section{Callinectes ornatus Ordway, 1863}

Distribution: Western Atlantic - Virginia, North Carolina to Florida, Gulf of Mexico, Antilles, Colombia, Venezuela, Guianas, and Brazil (from Amapá to Rio Grande do Sul).

Habitat: On sand and mud, and in less-saline waters. Intertidal to $75 \mathrm{~m}$.

Material examined: Stations 557, 1917.

Callinectes sapidus Rathbun, 1896

Distribution: Western Atlantic - From Virginia to Florida, Gulf of Mexico, Antilles, Central America, Venezuela, Brazil (from Bahia to Rio Grande do Sul) and Argentina. Eastern Atlantic - North, 
Mediterranean, Adriatic, and Black seas. Indo-Pacific - Japan.

Habitat: Intertidal zone to $90 \mathrm{~m}$. In bays, estuaries and lagoons.

Material examined: Stations 545, 550, 551, 557, 565, 1661, 1662, 1669.

Cronius ruber (Lamarck, 1818)

Distribution: Western Atlantic - Virginia, North Carolina to southern Florida, Gulf of Mexico, Central America, Antilles, northern South America and Brazil (from Amapá to Rio Grande do Sul). Eastern Atlantic - From Mauritania to Angola, Cape Verde, Principe, São Tomé and Annobon islands. Eastern Pacific From Baja California to Peru and Galapagos Islands.

Habitat: Sandy beaches, and rock and gravel areas. Shallow waters to $110 \mathrm{~m}$.

Material examined: Station 459.

Ovalipes trimaculatus (De Haan, 1833)

Distribution: Western Atlantic - Brazil (from São Paulo to Rio Grande do Sul), Uruguay, Argentina (including Patagonia). Eastern Atlantic - South Africa. Eastern Pacific - Chile and Peru. Indo-Pacific.

Habitat: On sand bottoms, occasionally on mud and shell bottoms. Aggressive species, generally buries itself in the sand for defense.

Material examined: Stations 310, 325, 463, 468, 571, $583,1643,1644,1646,1650,1659,1670,1687$, 1699, 1700, 1867, 1868, 1916, 1917, 1923, 1924.
Portunus spinicarpus (Stimpson, 1871)

Distribution: Western Atlantic - North and South Carolina, Florida, Gulf of Mexico, Antilles, Colombia, Venezuela, Guianas and Brazil (from Amapá to Rio Grande do Sul).

Habitat: Shallow waters to $550 \mathrm{~m}$. On sand, gravel, broken-shell, coral and mud bottoms.

Material examined: Stations 285, 290, 293, 296, 315, $330,362,363,369,378,387,399,402,405,410$, $413,419,425,429,436,439,442,445,448,449$, 452, 455, 457, 459, 460, 473, 539, 543, 569, 581, 592, 1664, 1667, 1696, 1703, 1712, 1722, 1723, 1758, 1859, 1891, 1907, 1940.

\section{Portunus spinimanus Latreille, 1819}

Distribution: Western Atlantic - From New Jersey to southern Florida, Bermuda, Gulf of Mexico, Antilles, Venezuela, Guianas and Brazil (from Pará to Rio Grande do Sul).

Habitat: Brackish water of channels and bays, on sand, gravel, broken-shell, and mud bottoms. From shallow waters to $90 \mathrm{~m}$.

Material examined: Stations 577, 579, 582, 585, 590, 1688.

\section{Superfamíly Xanthoidea MacLeay, 1838}

\section{FAMILY PANOPEIDAE Ortmann, 1893}

\section{Tetraxanthus rathbunae Chace, 1939}

Distribution: Western Atlantic - North Carolina, Florida, Gulf of Mexico, Antilles and Brazil (from Paraiba to Rio Grande do Sul).

Habitat: Mud, shell, coral, rock and sand bottoms. Between 100 and $500 \mathrm{~m}$, but in Brazil has been collected at 20 meters.

Material examined: Station 1675.
Cyrtoplax spinidentata (Benedict, 1892)

Distribution: Western Atlantic - Antilles and Brazil (from Pernambuco to Rio Grande do Sul).

Habitat: Mud bottoms; occasionally on sand or among algae. Shallow waters to $150 \mathrm{~m}$.

Material examined: Stations 288, 299, 320, 321, 328, 363 
FAMÍLY XANTHIDAE MacLeay, 1838

Speocarcinus carolinensis Stimpson, 1859

Distribution: Western Atlantic - North Carolina to Florida, Gulf of Mexico, Antilles and Brazil (Amapá, São Paulo and Rio Grande do Sul).

Habitat: In burrows of Squilla, Callianassa and other crustaceans, and in mud bottoms. From intertidal zone to $150 \mathrm{~m}$.

Material examined: Stations 413, 1662, 1868.

Superfamily Goneplacoidea MacLeay, 1838

FAMILY CHASMOCARCINIDAE Serène, 1964

Chasmocarcinus rathbuni Bouvier, 1917

Distribution: Western Atlantic - Brazil (Rio Grande do Sul).

Habitat: Preference for mud bottoms. Between 30 and $220 \mathrm{~m}$.

Material examined: Station 313.

Chasmocarcinus typicus Rathbun, 1898

Distribution: Western Atlantic - Antilles, northern South America, and Brazil (from Rio de Janeiro to Rio Grande do Sul).

Habitat: Mud bottoms; occasionally on sand. From 25 to $200 \mathrm{~m}$.

Material examined: Stations 293, 299, 305, 312, 374, 379, 402, 413, 419, 427, 432, 439, 459, 473, 559, $1656,1666,1675,1679,1691,1696,1697,1706$, 1712, 1718, 1723, 1758.
Speocarcinus meloi D`Incao \& Gomes da Silva, 1991 Distribution: Western Atlantic - Brazil (Rio Grande do Sul).

Habitat: Sand and mud bottoms and depths between 50 and $160 \mathrm{~m}$.

Material examined: Stations 313, 378 (Paratypes MZUSP-9578), 379 (Holotype MZUSP-9577), 413, 417, 421, 425, 427, 451, 1679, 1697, 1860, 1907.

\section{FAMILY EURYPLACIDAE Stimpson, 1871}

Frevillea hirsuta (Borradaile, 1916)

Distribution: Western Atlantic - North Carolina, Florida, Gulf of Mexico, and Brazil (from Amapá to Rio Grande do Sul).

Habitat: Prefers mud bottoms. Between 70 and $150 \mathrm{~m}$. Material examined: Stations 286, 413, 473, 588, 1883.

FAMILY PSEUDORHOMBILIDAE Alcock, 1900

Pseudorhombila octodentata Rathbun, 1906

Distribution: Western Atlantic - Antilles and Brazil (from Rio de Janeiro to Rio Grande do Sul).

Habitat: Depths down to $200 \mathrm{~m}$. Prefers mud bottoms. Material examined: Stations 285, 286, 288, 316, 374, $378,413,418,421,425,439,451,452,456,459$, $473,552,582,588$.

\section{Superfamily Grapsoidea MacLeay, 1838}

FAMÍLY PLAGUSIIDAE Dana, 1851

Euchirograpsus antillensis Türkay, 1975

Distribution: Western Atlantic - Florida, Antilles,
Venezuela, and Brazil (São Paulo and Rio Grande do Sul).

Habitat: Prefers sand bottoms. Between 15 and $415 \mathrm{~m}$. Material examined: Station 458. 


\section{Superfamily Palicoidea Bouvier, 1898}

FAMILY PALICIDAE Bouvier, 1898

\section{Palicus alternatus Rathbun, 1897}

Distribution: Western Atlantic - North Carolina, Florida, Gulf of Mexico and Brazil (from Rio de Janeiro to Rio Grande do Sul).

Habitat: Sand, gravel, broken-shell, coral and mud bottoms. From shallow waters to $110 \mathrm{~m}$.

Material examined: Stations 1674, 1711.

Palicus dentatus (A. Milne-Edwards, 1880)

Distribution: Western Atlantic - Florida, Gulf of Mexico, Antilles and Brazil (from Rio de Janeiro to Rio Grande do Sul).

Habitat: Coral and broken-shell bottoms. From 30 to $140 \mathrm{~m}$ depth.

Material examined: Stations 1674, 1883.

\section{DISCUSSION}

The cryophilic species of the Magellanic (coldtemperate) and Argentinian (warm-temperate) distribution patterns possess specific characteristics of thermal tolerance, as shown by the northern limits of their distributions. Whereas the Magellanic species occur only as far north as Rio Grande do Sul, the Argentinian species extend to the warmer waters of the coast of Rio de Janeiro (Melo 1985).

The Magellanic species are probably derived from the so-called Chilean meridional fauna (Boschi 1966). Their distribution appears to show that the southern East Pacific and the southern West Atlantic constitute a biogeographical unit. Seven species $(12.2 \%)$ found in the region studied are from Magellanic origin, or subantarctic waters: Eurypodius latreillei, Libidoclaea granaria, Peltarion spinulosum, Corystoides chilensis, Bellia picta, Collodes rostratus and Leurocyclus tuberculosus. All of these species also occur on the Chilean coast.

The species of the Argentinian pattern show characteristics of a subtropical fauna, or of warmtemperate waters. Under the influence of the Malvinas
Palicus obesus (A. Milne-Edwards, 1880)

Distribution: Western Atlantic - Florida, Gulf of Mexico, Mexico and Brazil (from Rio de Janeiro to Rio Grande do Sul).

Habitat: Preferentially on mud bottoms, between 20 and $220 \mathrm{~m}$.

Material examined: Stations 279, 569, 579.

Palicus sica (A. Milne-Edwards, 1880)

Distribution: Western Atlantic - South Carolina, Florida, Gulf of Mexico, Antilles and Brazil (from Amapá to Rio Grande do Sul).

Habitat: Sand, mud, broken-shell and coral bottoms. From shallow waters to $190 \mathrm{~m}$.

Material examined: Stations 279, 438, 443, 465, 569, 1646, 1648, 1656, 1674, 1740, 1883.

Current, they normally extend north to Cabo Frio in Rio de Janeiro, where the local upwelling prevents them from passing this limit. Five species of this pattern ( $8.6 \%$ ) were found on the coast of Rio Grande do Sul:, Rochinia gracilipes, Podochela atlantica, Libinia spinosa, Pelia rotunda and Spinolambrus fraterculus.

The Carolinian (warm-temperate waters) and Caribbean (tropical) patterns showed the highest numbers of species in the region studied, since these species exploit the warm waters of the Brazil Current, to reach to Rio Grande do Sul and Uruguay. Fifteen species of Carolinian origin (25.8\%) and 12 tropical species (20.7\%) were collected by the GEDIP Project.

Nine Virginian species (15.5\%), of coldtemperate waters, which seek out deeper waters, extend to the region.

Three species $(5.0 \%)$, all in the family Portunidae: Callinectes sapidus, Cronius ruber and Ovalipes trimaculatus, with circumtropical distribution, were found.

Apiomithrax violaceus, Moreiradromia antillensis and Hepatus pudibundus were the three 
species (5.0\%) with an amphi-Atlantic distribution that was collected.

The rate of endemism was relatively low $(7.2 \%)$. Only 4 species endemic to the region were found, demonstrating that the region has not undergone long periods of isolation.

MELO-FILHO, G.A.S. \& MELO, G.A.S. 2001. Espécies do gênero Munida Leach (Crustacea: Decapoda: Galatheidae) coletadas entre Torres (Rio Grande do Sul, Brasil) e Maldonado (Uruguai) pelo programa Rio Grande do Sul (PRS I-II, GEDIP). Revta Brasil. Zool, Curitiba, 18 (4): 1177-1196.

MIRANDA, L.B. 1971. Relatório sobre as condições oceanográficas na plataforma continental do Rio Grande do Sul. Contr. Inst. Oceanogr. Univ. São Paulo, ser. Oceanografia Física, São Paulo, 14: 1-161.

MIRANDA, L.B.; LUEDMANN, E.F. \& MYIAO, S. Y. 1973. Distribuição da temperatura, salinidade e circulação geral em superfície. In: GEDIP - Grupo Executivo do Desenvolvimento da Indústria da Pesca \& Instituto Oceanográfico da Universidade de São Paulo. Relatório sobre a segunda pesquisa oceanográfica e pesqueira do Atlântico Sul entre Torres e Maldonado (Lat. 29 S - 35 ㅇ), Programa Rio Grande do Sul II. Parte II. São Paulo, GEDIP/IOUSP. p. 1-82.

MOREIRA, P.S. 1973. Espécies de Isopoda (Crustacea: Peracarida). In: GEDIP-Grupo Executivo do Desenvolvimento da Indústria da Pesca \& Instituto Oceanográfico da Universidade de São Paulo. Relatório sobre a segunda pesquisa oceanográfica e pesqueira do Atlântico Sul entre Torres e Maldonado (Lat. 29ㅇ - 35오), Programa Rio Grande do Sul II. Parte I. São Paulo, GEDIP/IOUSP. p. 213-229.

NAVAS-PEREIRA, D. 1973. Análise qualitativa e quantitativa do Zooplancton. In: GEDIP- Grupo Executivo do Desenvolvimento da Indústria da Pesca \& Instituto Oceanográfico da Universidade de São Paulo. Relatório sobre a segunda pesquisa oceanográfica e pesqueira do Atlântico Sul entre Torres e Maldonado (Lat. 29S-35오), Programa Rio Grande do Sul II. Parte I. São Paulo, GEDIP/IOUSP. p. 29-92.

NG, P.K.L.; GUINOT, D. \& DAVIE, P.J.F. 2008. Systema Brachyurorum: Part I. An annotated checklist of extant brachyuran crabs of the world. Raffles Bull. Zool., 17: 1-286

NONATO, E.F. 1973. Anelídeos poliquetas. In : GEDIP - Grupo Executivo do Desenvolvimento da Indústria da Pesca \& Instituto Oceanográfico da Universidade de São Paulo. Relatório sobre a segunda pesquisa oceanográfica e pesqueira do Atlântico Sul, entre Torres e Maldonado (Lat. 29은옹), Programa Rio Grande do Sul II. Parte I. São Paulo, GEDIP/IOUSP. p. 231-232.

RIBEIRO, C.V.; BARBOSA, R.R.; MORAES, B.M. \& GROSSER, K.M. 1973. Nota preliminar sobre Porifera. In: GEDIP - Grupo Executivo do Desenvolvimento da Indústria da Pesca \& Instituto Oceanográfico da Universidade de São Paulo. Relatório sobre a segunda pesquisa oceanográfica e pesqueira do Atlântico Sul, entre Torres e Maldonado (Lat. 29오- 35오), Programa Rio Grande do Sul II. Parte I. São Paulo, GEDIP/IOUSP. p. 233-237. 
SADOWSKY, V. 1973. Relação dos peixes cartilaginosos. In: GEDIP- Grupo Executivo do Desenvolvimento da Indústria da Pesca \& Instituto Oceanográfico da Universidade de São Paulo. Relatório sobre a segunda pesquisa oceanográfica e pesqueira do Atlântico Sul, entre Torres e Maldonado (Lat. 29ㅇ-35S), Programa Rio Grande do Sul II. Parte I. São Paulo, GEDIP/IOUSP. p. 483-488.

SCELZO, M.A. 2001. First Record of the portunid crab Arenaeus cribrarius (Lamarck, 1818) (Crustacea: Brachyura: Portunidae) in marine waters of Argentina. Proc. Biol. Soc. Wash., 114(3): 605-610.

TOMMASI, L.R.; BORDIN, G. \& OLIVEIRA, I.R. 1973a. Distribuição dos macro-crustacea (exceto Penaeidea). In: GEDIP - Grupo Executivo do Desenvolvimento da Indústria da Pesca \& Instituto Oceanográfico da Universidade de São Paulo. Relatório sobre a segunda pesquisa oceanográfica e pesqueira do Atlântico Sul, entre Torres e Maldonado (Lat. 29S-35S), Programa Rio Grande do Sul II. Parte I. São Paulo, GEDIP/IOUSP. p. 163-173.

TOMMASI, L.R.; CARRERA-RODRIGUES, C.; ADAIME, R.R. \& RODRIGUES, S.C. 1973b. Distribuição dos Echinodermata. In: GEDIP - Grupo Executivo do Desenvolvimento da Indústria da Pesca \& Instituto Oceanográfico da Universidade de São Paulo. Relatório sobre a segunda pesquisa oceanográfica e pesqueira do Atlântico Sul, entre Torres e Maldonado (Lat. 29응 S- 35ㅇ), Programa Rio Grande do Sul II. Parte I. São Paulo, GEDIP/IOUSP. p. 193-206.

TOMMASI, L.R. \& RIOS, E.C. 1973. Distribuição dos Pelecipoda e Gastropoda. In: GEDIP-Grupo Executivo do Desenvolvimento da Indústria da Pesca \& Instituto Oceanográfico da Universidade de São Paulo. Relatório sobre a segunda pesquisa oceanográfica e pesqueira do Atlântico Sul, entre Torres e Maldonado (Lat. 29S-35오), Programa Rio Grande do Sul II. Parte I. São Paulo, GEDIP/IOUSP. p. 183-192.

VAZZOLER, G. 1975. Distribuição da fauna de peixes demersais e ecologia dos Sciaenidae da plataforma continental brasileira, entre as latitudes 2921' S (Torres) e 334'S (Chuí). Bolm. Inst. Oceanogr., São Paulo, 24: 85-169.

VAZZOLER, G.; KAWAKAMI, E. \& ZANETI, E.M. 1973. Distribuição e abundância de peixes demersais. In: GEDIP- Grupo Executivo do Desenvolvimento da Indústria da Pesca \& Instituto Oceanográfico da Universidade de São Paulo. Relatório sobre a segunda pesquisa oceanográfica e pesqueira do Atlântico Sul, entre Torres e Maldonado (Lat. 29은오), Programa Rio Grande do Sul II. Parte I. São Paulo, GEDIP/IOUSP. p. 307-426.

WAKABARA, Y. 1973. Levantamento dos Amphipoda. In: GEDIP Grupo Executivo do Desenvolvimento da Indústria da Pesca \& Instituto Oceanográfico da Universidade de São Paulo. Relatório sobre a segunda pesquisa oceanográfica e pesqueira do Atlântico Sul, entre Torres e Maldonado (Lat. 29오-35오), Programa Rio Grande do Sul II. Parte I. São Paulo, GEDIP/IOUSP. p. 175-182. 
Table I. Collection stations (coordinates, date, depth, temperature, salinity, species and number of species)

\begin{tabular}{|c|c|c|c|c|c|c|c|c|}
\hline Stations & Latitude & Longitude & Date & Depth & Temperature & Salinity & Species & $\begin{array}{c}\text { № of } \\
\text { species }\end{array}$ \\
\hline 275 & $33: 55$ & $53: 20$ & $24 / 04 / 68$ & 21 & 17.21 & 28.279 & $\begin{array}{l}\text { Leurocyclus tuberculosus, } \\
\text { Libinia spinosa }\end{array}$ & 2 \\
\hline 277 & $34: 32$ & $52: 22$ & $25 / 04 / 68$ & 60 & 16.79 & 33.896 & Leurocyclus tuberculosus & 1 \\
\hline 279 & $34: 19$ & $51: 43$ & $25 / 04 / 68$ & 154 & 20.86 & 36.493 & $\begin{array}{l}\text { Palicus obesus, Palicus } \\
\text { sica, Spinolambrus } \\
\text { pourtalesii, Leurocyclus } \\
\text { tuberculosus }\end{array}$ & 4 \\
\hline 280 & $34: 05$ & $52: 11$ & $26 / 04 / 68$ & 60 & 17.40 & 34.105 & $\begin{array}{l}\text { Leurocyclus tuberculosus, } \\
\text { Stenocionops furcatus }\end{array}$ & 2 \\
\hline 281 & $33: 52$ & $52: 37$ & $26 / 04 / 68$ & 30 & 17.97 & 32.588 & Leurocyclus tuberculosus & 1 \\
\hline 282 & $33: 52$ & $52: 53$ & $26 / 04 / 68$ & 15 & 17.35 & 27.487 & Libinia spinosa & 1 \\
\hline 285 & $33: 40$ & $51: 42$ & $27 / 04 / 68$ & 92 & 18.51 & 36.077 & $\begin{array}{l}\text { Pseudorhombila } \\
\text { octodentata, Portunus } \\
\text { spinicarpus }\end{array}$ & 2 \\
\hline 286 & $33: 58$ & $51: 19$ & $27 / 04 / 68$ & 604 & 11.17 & 34.986 & $\begin{array}{l}\text { Pseudorhombila } \\
\text { octodentata, Frevillea } \\
\text { hirsuta }\end{array}$ & 2 \\
\hline 288 & $33: 19$ & $51: 20$ & $28 / 04 / 68$ & 71 & 20.72 & 36.158 & $\begin{array}{l}\text { Pseudorhombila } \\
\text { octodentata, Cyrtoplax } \\
\text { spinidentata }\end{array}$ & 2 \\
\hline 289 & $32: 58$ & $51: 49$ & $28 / 04 / 68$ & 42 & 18.65 & 33.248 & $\begin{array}{l}\text { Leurocyclus tuberculosus, } \\
\text { Libinia spinosa }\end{array}$ & 2 \\
\hline 290 & $32: 16$ & $51: 58$ & $28 / 04 / 68$ & 21 & 17.94 & 30.160 & Portunus spinicarpus & 1 \\
\hline 291 & $29: 35$ & $49: 48$ & $20 / 06 / 68$ & 25 & 17.22 & 33.016 & $\begin{array}{l}\text { Leurocyclus tuberculosus, } \\
\text { Libinia spinosa }\end{array}$ & 2 \\
\hline 293 & $30: 06$ & $48: 56$ & $21 / 06 / 68$ & 133 & 18.43 & 36.126 & $\begin{array}{l}\text { Chasmocarcinus typicus, } \\
\text { Chasmocarcinus rathbuni, } \\
\text { Portunus spinicarpus }\end{array}$ & 3 \\
\hline 296 & $30: 33$ & 49:21 & $22 / 06 / 68$ & 150 & 17.40 & 35.935 & Portunus spinicarpus & 1 \\
\hline 299 & $30: 42$ & $50: 06$ & $22 / 06 / 68$ & 68 & 18.19 & 34.996 & $\begin{array}{l}\text { Chasmocarcinus typicus, } \\
\text { Cyrtoplax spinidentata, } \\
\text { Libinia spinosa }\end{array}$ & 3 \\
\hline 305 & $31: 41$ & $50: 29$ & $24 / 06 / 68$ & 103 & 19.06 & 35.894 & Chasmocarcinus typicus & 1 \\
\hline 310 & $31: 48$ & $51: 22$ & $25 / 06 / 68$ & 22 & 14.20 & 39.297 & $\begin{array}{l}\text { Libinia spinosa, Ovalipes } \\
\text { trimaculatus }\end{array}$ & 2 \\
\hline 312 & $32: 27$ & $51: 22$ & $26 / 06 / 68$ & 57 & 14.05 & 33.626 & Chasmocarcinus typicus & 1 \\
\hline 313 & $32: 45$ & $50: 55$ & $26 / 06 / 68$ & 78 & 15.16 & 34.639 & $\begin{array}{l}\text { Chasmocarcinus rathbuni, } \\
\text { Speocarcinus meloi, } \\
\text { Moreiradromia antillensis, }\end{array}$ & 3 \\
\hline 315 & $33: 28$ & $50: 46$ & $26 / 06 / 68$ & 166 & 18.29 & 36.102 & $\begin{array}{l}\text { Acanthocarpus alexandri, } \\
\text { Persephona } \\
\text { mediterranea,Portunus } \\
\text { spinicarpus }\end{array}$ & 3 \\
\hline 316 & $33: 10$ & $51: 14$ & $27 / 06 / 68$ & 72 & 12.80 & 33.593 & $\begin{array}{l}\text { Pseudorhombila } \\
\text { octodentata }\end{array}$ & 1 \\
\hline 320 & $33: 15$ & $52: 02$ & $28 / 06 / 68$ & 47 & 12.99 & 33.066 & Cyrtoplax spinidentata & 1 \\
\hline 321 & $33: 30$ & $51: 40$ & $28 / 06 / 68$ & 85 & 12.43 & 33.630 & Cyrtoplax spinidentata & 1 \\
\hline 324 & $33: 58$ & $52: 00$ & $29 / 06 / 68$ & 47 & 17.74 & 33.517 & Libinia spinosa & 1 \\
\hline 325 & $33: 45$ & $52: 25$ & $29 / 06 / 68$ & 28 & 13.03 & 32.868 & $\begin{array}{l}\text { Leurocyclus tuberculosus, } \\
\text { Ovalipes trimaculatus }\end{array}$ & 2 \\
\hline 328 & $34: 04$ & $52: 46$ & $29 / 06 / 68$ & 44 & 12.87 & 32.832 & $\begin{array}{l}\text { Leurocyclus tuberculosus, } \\
\text { Cyrtoplax spinidentata }\end{array}$ & 2 \\
\hline 330 & $34: 35$ & $52: 00$ & $30 / 06 / 68$ & 148 & 17.70 & 35.970 & $\begin{array}{l}\text { Myropsis quinquespinosa, } \\
\text { Portunus spinicarpus }\end{array}$ & 2 \\
\hline 362 & $30: 29$ & $49: 19$ & $17 / 08 / 68$ & 128 & 17.12 & 35.919 & Portunus spinicarpus & 1 \\
\hline 363 & $30: 09$ & 49:35 & $17 / 08 / 68$ & 60 & 18.85 & 36.090 & $\begin{array}{l}\text { Portunus spinicarpus, } \\
\text { Cyrtoplax spinidentata }\end{array}$ & 2 \\
\hline 364 & $29: 53$ & $50: 00$ & $17 / 08 / 68$ & 23 & 17.30 & 34.301 & $\begin{array}{l}\text { Hepatus pudibundus, } \\
\text { Libinia spinosa, }\end{array}$ & 2 \\
\hline
\end{tabular}


Table I. (cont.) Collection stations (coordinates, date, depth, temperature, salinity, species and number of species)

continuação

\begin{tabular}{|c|c|c|c|c|c|c|c|c|}
\hline 365 & $30: 26$ & $50: 09$ & $18 / 08 / 68$ & 21 & 17.39 & 33.642 & Libinia spinosa & 1 \\
\hline 367 & $30: 54$ & $49: 23$ & $20 / 08 / 68$ & 184 & 14.69 & 35.490 & Latreillia williamsi & 1 \\
\hline 368 & $31: 22$ & $49: 42$ & $20 / 08 / 68$ & 200 & 16.38 & 35.748 & Latreillia williamsi & 1 \\
\hline 369 & $31: 07$ & $50: 05$ & $21 / 08 / 68$ & 114 & 17.05 & 35.879 & Portunus spinicarpus & 1 \\
\hline 371 & $31: 18$ & $50: 48$ & $21 / 08 / 68$ & 25 & 17.98 & 35.216 & Libinia spinosa & 1 \\
\hline 374 & $32: 18$ & $50: 13$ & $23 / 08 / 68$ & 148 & 18.02 & 35.662 & $\begin{array}{l}\text { Chasmocarcinus typicus, } \\
\text { Myropsis quinquespinosa, } \\
\text { Pseudorhombila octodentata }\end{array}$ & 3 \\
\hline 378 & $32: 15$ & $51: 16$ & $24 / 08 / 68$ & 57 & 17.54 & 35.277 & $\begin{array}{l}\text { Homola mínima, Speocarcinus } \\
\text { meloi, Pseudorhombila } \\
\text { octodentata, Portunus spinicarpus }\end{array}$ & 4 \\
\hline 379 & $32: 32$ & $50: 51$ & $24 / 08 / 68$ & 70 & 18.45 & 36.012 & $\begin{array}{l}\text { Chasmocarcinus typicus, } \\
\text { Speocarcinus meloi, }\end{array}$ & 2 \\
\hline 383 & $32: 40$ & $51: 37$ & $25 / 08 / 68$ & 46 & 15.78 & 33.557 & Persephona mediterranea & 1 \\
\hline 387 & $33: 23$ & $51: 28$ & $25 / 08 / 68$ & 82 & 15.70 & 35.401 & Portunus spinicarpus & 1 \\
\hline 395 & $34: 10$ & $52: 14$ & $27 / 08 / 68$ & 62 & 12.80 & 33.874 & Hepatus pudibundus & 1 \\
\hline 396 & $34: 26$ & $51: 47$ & $27 / 08 / 68$ & 155 & 14.73 & 35.528 & $\begin{array}{l}\text { Hepatus pudibundus, Latreillia } \\
\text { williamsi, Homola minima. }\end{array}$ & 3 \\
\hline 397 & $29: 45$ & $49: 55$ & $25 / 10 / 68$ & 26 & 17.96 & 35.639 & $\begin{array}{l}\text { Hepatus pudibundus, } \\
\text { Persephona mediterranea, } \\
\text { Libinia spinosa }\end{array}$ & 3 \\
\hline 399 & $30: 17$ & $49: 07$ & $25 / 10 / 68$ & 135 & 15.58 & 35.596 & Portunus spinicarpus & 1 \\
\hline 401 & $30: 50$ & $49: 15$ & $26 / 10 / 68$ & 183 & 14.88 & 35.540 & Latreillia williamsi & 1 \\
\hline 402 & $30: 33$ & $49: 43$ & $26 / 10 / 68$ & 98 & 16.08 & 35.710 & $\begin{array}{l}\text { Hepatus pudibundus, } \\
\text { Chasmocarcinus typicus, } \\
\text { Persephona mediterranea, } \\
\text { Portunus spinicarpus }\end{array}$ & 4 \\
\hline 403 & $30: 14$ & $50: 08$ & $26 / 10 / 68$ & 24 & 18.33 & 35.770 & $\begin{array}{l}\text { Hepatus pudibundus, Persephona } \\
\text { mediterranea, Libinia spinosa }\end{array}$ & 3 \\
\hline 405 & $34: 34$ & $52: 29$ & $29 / 10 / 68$ & 65 & 9.83 & 33.557 & $\begin{array}{l}\text { Peltarion spinulosum, Collodes } \\
\text { rostratus, Libinia spinosa, } \\
\text { Stenocionops furcatus, Portunus } \\
\text { spinicarpus, Rochinia gracilipes }\end{array}$ & 6 \\
\hline 406 & $34: 12$ & $52: 51$ & $30 / 10 / 68$ & 65 & 13.74 & 33.703 & $\begin{array}{l}\text { Leurocyclus tuberculosus, Libinia } \\
\text { spinosa }\end{array}$ & 2 \\
\hline 407 & $33: 53$ & $53: 23$ & $30 / 10 / 68$ & 18 & 17.15 & 31.227 & $\begin{array}{l}\text { Corystoides chilensis, Hepatus } \\
\text { pudibundus, Libinia spinosa }\end{array}$ & 3 \\
\hline 408 & $33: 33$ & $52: 55$ & $30 / 10 / 68$ & 19 & 17.41 & 31.546 & Libinia spinosa & 1 \\
\hline 409 & $33: 47$ & $52: 35$ & $30 / 10 / 68$ & 32 & 16.29 & 33.564 & $\begin{array}{l}\text { Corystoides chilensis, Hepatus } \\
\text { pudibundus, Collodes rostratus, } \\
\text { Libinia spinosa }\end{array}$ & 4 \\
\hline 410 & $34: 03$ & $52: 07$ & $31 / 10 / 68$ & 60 & 11.71 & 33.459 & $\begin{array}{l}\text { Leurocyclus tuberculosus, } \\
\text { Portunus spinicarpus }\end{array}$ & 2 \\
\hline 411 & $34: 19$ & $51: 42$ & $31 / 10 / 68$ & 196 & 15.68 & 35.752 & $\begin{array}{l}\text { Osachila tuberosa, Latreillia } \\
\text { williamsi,Spinolambrus fraterculus }\end{array}$ & 3 \\
\hline 412 & $33: 54$ & $51: 23$ & $31 / 10 / 68$ & 165 & 16.96 & 35.979 & $\begin{array}{l}\text { Latreillia williamsi, Stenocionops } \\
\text { furcatus, Spinolambrus pourtalesii }\end{array}$ & 3 \\
\hline 413 & $33: 37$ & $51: 41$ & $31 / 10 / 68$ & 78 & 16.20 & 34.985 & $\begin{array}{l}\text { Chasmocarcinus typicus, } \\
\text { Speocarcinus carolinensis, } \\
\text { Pseudorhombila octodentata, } \\
\text { Frevillea hirsuta, Leurocyclus } \\
\text { tuberculosus, Portunus spinicarpus, } \\
\text { Speocarcinus meloi }\end{array}$ & 7 \\
\hline 414 & $33: 26$ & $52: 09$ & $01 / 11 / 68$ & 50 & 16.60 & 33.996 & Libinia spinosa & 1 \\
\hline 416 & $32: 45$ & $52: 20$ & $01 / 11 / 68$ & 148 & 18.80 & 32.188 & Callinectes danae & 1 \\
\hline 417 & $33: 00$ & $51: 50$ & $01 / 11 / 68$ & 50 & 16.66 & 34.785 & $\begin{array}{l}\text { Mesorhoea sexspinosa, } \\
\text { Speocarcinus meloi }\end{array}$ & 2 \\
\hline 418 & $33: 18$ & $51: 21$ & $02 / 11 / 68$ & 69 & 16.44 & 35.039 & Pseudorhombila octodentata & 1 \\
\hline 419 & $33: 36$ & $50: 53$ & $02 / 11 / 68$ & 190 & 15.67 & 35.726 & $\begin{array}{l}\text { Chasmocarcinus typicus, Portunus } \\
\text { spinicarpus }\end{array}$ & 2 \\
\hline
\end{tabular}


Table I. (cont.) Collection stations (coordinates, date, depth, temperature, salinity, species and number of species)

continuação

\begin{tabular}{|c|c|c|c|c|c|c|c|c|}
\hline 421 & $32: 53$ & $51: 01$ & $03 / 11 / 68$ & 68 & 17.13 & 35.374 & $\begin{array}{l}\text { Speocarcinus meloi, } \\
\text { Pseudorhombila octodentata }\end{array}$ & 2 \\
\hline 425 & $32: 08$ & $51: 10$ & $04 / 11 / 68$ & 57 & 17.68 & 35.716 & $\begin{array}{l}\text { Speocarcinus meloi, } \\
\text { Pseudorhombila octodentata, Libinia } \\
\text { spinosa, Mesorhoea sexspinosa, } \\
\text { Portunus spinicarpus }\end{array}$ & 5 \\
\hline 427 & $32: 34$ & $50: 29$ & $04 / 11 / 68$ & 122 & 17.53 & 35.863 & $\begin{array}{l}\text { Chasmocarcinus typicus, } \\
\text { Speocarcinus meloi, }\end{array}$ & 2 \\
\hline 429 & $31: 51$ & $50: 37$ & $05 / 11 / 68$ & 89 & 16.69 & 35.820 & Portunus spinicarpus & 1 \\
\hline 430 & $31: 33$ & $51: 05$ & $05 / 11 / 68$ & 200 & 19.02 & 35.311 & Libinia spinosa & 1 \\
\hline 431 & $31: 10$ & $50: 41$ & $05 / 11 / 68$ & 19 & 17.90 & 35.735 & Libinia spinosa & 1 \\
\hline 432 & $31: 25$ & $50: 17$ & $06 / 11 / 68$ & 112 & 16.17 & 35.779 & Chasmocarcinus typicus & 1 \\
\hline 434 & $29: 34$ & $49: 50$ & $04 / 12 / 68$ & 25 & 16.77 & 35.766 & Leurocyclus tuberculosus & 1 \\
\hline 436 & $30: 15$ & 49:00 & $04 / 12 / 68$ & 140 & 15.77 & 35.702 & Portunus spinicarpus & 1 \\
\hline 437 & $30: 23$ & $48: 37$ & $04 / 12 / 68$ & 195 & 14.89 & 35.577 & Anomalothir furcillatus & 1 \\
\hline 438 & $30: 40$ & 49:09 & $05 / 12 / 68$ & 172 & 15.27 & 35.631 & Palicus sica, Latreillia williamsi & 2 \\
\hline 439 & $30: 22$ & $49: 36$ & $05 / 12 / 68$ & 92 & 16.05 & 35.707 & $\begin{array}{l}\text { Chasmocarcinus typicus, } \\
\text { Pseudorhombila octodentata, } \\
\text { Portunus spinicarpus }\end{array}$ & 3 \\
\hline 441 & $30: 34$ & $50: 17$ & $05 / 12 / 68$ & 19 & 19.06 & 35.808 & Libinia spinosa & 1 \\
\hline 442 & $30: 50$ & $49: 54$ & $06 / 12 / 68$ & 122 & 15.75 & 35.693 & Portunus spinicarpus & 1 \\
\hline 443 & $31: 06$ & $49: 30$ & $06 / 12 / 68$ & 208 & 16.03 & 35.754 & Palicus sica & 1 \\
\hline 444 & $31: 31$ & $49: 47$ & $06 / 12 / 68$ & 294 & 17.64 & 35.859 & Spinolambrus pourtalesii & 1 \\
\hline 445 & $31: 16$ & $50: 14$ & $06 / 12 / 68$ & 117 & 16.35 & 35.785 & Portunus spinicarpus & 1 \\
\hline 447 & $31: 25$ & $50: 58$ & $07 / 12 / 68$ & 25 & 20.80 & 35.675 & Libinia spinosa & 1 \\
\hline 448 & $31: 42$ & $50: 31$ & $07 / 12 / 68$ & 98 & 16.55 & 35.788 & Portunus spinicarpus & 1 \\
\hline 449 & $32: 00$ & $50: 05$ & $07 / 12 / 68$ & 185 & 14.33 & 35.502 & $\begin{array}{l}\text { Stenocionops furcatus, Heterocrypta } \\
\text { lapidea, Portunus spinicarpus }\end{array}$ & 3 \\
\hline 451 & $32: 14$ & $50: 40$ & $08 / 12 / 68$ & 84 & 16.83 & 35.908 & $\begin{array}{l}\text { Speocarcinus meloi, } \\
\text { Pseudorhombila octodentata }\end{array}$ & 2 \\
\hline 452 & $32: 00$ & $51: 00$ & $08 / 12 / 68$ & 66 & 18.07 & 35.844 & $\begin{array}{l}\text { Pseudorhombila octodentata, Libinia } \\
\text { spinosa,Portunus spinicarpus }\end{array}$ & 3 \\
\hline 455 & $32: 24$ & $51: 25$ & $08 / 12 / 68$ & 51 & 18.99 & 35.615 & $\begin{array}{l}\text { Collodes rostratus, Libinia spinosa, } \\
\text { Portunus spinicarpus }\end{array}$ & 3 \\
\hline 456 & $32: 46$ & $50: 59$ & $09 / 12 / 68$ & 66 & 17.51 & 35.526 & Pseudorhombila octodentata & 1 \\
\hline 457 & 33:01 & $50: 33$ & $09 / 12 / 68$ & 108 & 17.04 & 36.094 & Portunus spinicarpus & 1 \\
\hline 458 & $33: 29$ & $50: 44$ & $09 / 12 / 68$ & 207 & 14.58 & 35.728 & $\begin{array}{l}\text { Moreiradromia antillensis, } \\
\text { Euchirograpsus antillensis, } \\
\text { Anomalothir furcillatus, }\end{array}$ & 3 \\
\hline 459 & $33: 10$ & $51: 14$ & $09 / 12 / 68$ & 72 & 15.44 & 35.228 & $\begin{array}{l}\text { Chasmocarcinus typicus, } \\
\text { Pseudorhombila octodentata, } \\
\text { Cronius ruber, Portunus spinicarpus }\end{array}$ & 4 \\
\hline 460 & $32: 51$ & $51: 44$ & $10 / 12 / 68$ & 46 & 19.40 & 35.081 & $\begin{array}{l}\text { Persephona mediterranea, Myropsis } \\
\text { quinquespinosa, Leurocyclus } \\
\text { tuberculosus, Libinia spinosa, } \\
\text { Portunus spinicarpus }\end{array}$ & 5 \\
\hline 463 & $34: 00$ & $52: 48$ & $11 / 12 / 68$ & 294 & 16.40 & 33.875 & $\begin{array}{l}\text { Libinia spinosa, Ovalipes } \\
\text { trimaculatus }\end{array}$ & 2 \\
\hline 464 & $34: 19$ & $52: 22$ & $11 / 12 / 68$ & 63 & 12.22 & 34.008 & Persephona mediterranea & 1 \\
\hline 465 & $34: 35$ & $51: 56$ & $11 / 12 / 68$ & 338 & 9.77 & 34.826 & $\begin{array}{l}\text { Acanthocarpus alexandri, } \\
\text { Euprognatha rastellifera, Palicus } \\
\text { sica }\end{array}$ & 3 \\
\hline 467 & 33:57 & $51: 58$ & $12 / 12 / 68$ & 61 & 15.85 & 35.288 & Libinia spinosa & 1 \\
\hline 468 & $33: 41$ & $52: 23$ & $12 / 12 / 68$ & 26 & 18.46 & 34.801 & $\begin{array}{l}\text { Leurocyclus tuberculosus, Libinia } \\
\text { spinosa, Ovalipes trimaculatus }\end{array}$ & 3 \\
\hline
\end{tabular}


continuação

Table I. (cont.) Collection stations (coordinates, date, depth, temperature, salinity, species and number of species)

\begin{tabular}{|c|c|c|c|c|c|c|c|c|}
\hline 470 & $32: 59$ & $52: 28$ & $13 / 12 / 68$ & 15 & 22.85 & 33.062 & $\begin{array}{l}\text { Persephona mediterranea, Libinia } \\
\text { spinosa }\end{array}$ & 2 \\
\hline 471 & $33: 16$ & $52: 04$ & $13 / 12 / 68$ & 41 & 18.03 & 35.090 & $\begin{array}{l}\text { Hepatus pudibundus, Leurocyclus } \\
\text { tuberculosus, Libinia spinosa }\end{array}$ & 3 \\
\hline 473 & $33: 47$ & $51: 16$ & $14 / 12 / 68$ & 138 & 14.98 & 35.592 & $\begin{array}{l}\text { Acanthocarpus alexandri, } \\
\text { Chasmocarcinus typicus, } \\
\text { Pseudorhombila octodentata, } \\
\text { Frevillea hirsuta, Portunus } \\
\text { spinicarpus }\end{array}$ & 5 \\
\hline 538 & 29:34 & 49:09 & $05 / 03 / 69$ & 76 & 17.27 & 35.879 & $\begin{array}{l}\text { Hepatus pudibundus, Persephona } \\
\text { mediterranea, Leurocyclus } \\
\text { tuberculosus }\end{array}$ & 3 \\
\hline 539 & 29:52 & $48: 41$ & $05 / 03 / 69$ & 138 & 15.64 & 35.679 & $\begin{array}{l}\text { Latreillia williamsi, Portunus } \\
\text { spinicarpus }\end{array}$ & 2 \\
\hline 541 & $30: 30$ & $48: 44$ & $06 / 03 / 69$ & 208 & 15.35 & 35.630 & Latreillia williamsi & 1 \\
\hline 543 & $29: 59$ & 49:37 & $06 / 03 / 69$ & 54 & 22.93 & 36.025 & $\begin{array}{l}\text { Leurocyclus tuberculosus, Libinia } \\
\text { spinosa,Portunus spinicarpus }\end{array}$ & 3 \\
\hline 544 & $29: 43$ & 49:55 & $07 / 03 / 69$ & 23 & 24.58 & 34.979 & $\begin{array}{l}\text { Hepatus pudibundus, Persephona } \\
\text { mediterranea, }\end{array}$ & 2 \\
\hline 545 & $30: 14$ & $50: 09$ & $07 / 03 / 69$ & 22 & 25.10 & 24.535 & Callinectes sapidus & 1 \\
\hline 547 & $30: 48$ & $49: 18$ & $07 / 03 / 69$ & 160 & 16.29 & 35.781 & $\begin{array}{l}\text { Latreillia williamsi, Podochela } \\
\text { atlantica }\end{array}$ & 2 \\
\hline 549 & $30: 59$ & 49:59 & $08 / 03 / 69$ & 114 & 17.41 & 35.932 & Libinia spinosa & 1 \\
\hline 550 & $30: 44$ & $50: 25$ & $08 / 03 / 69$ & 19 & 24.45 & 33.978 & $\begin{array}{l}\text { Hepatus pudibundus, Libinia } \\
\text { spinosa, Microphrys bicornutus, } \\
\text { Callinectes sapidus }\end{array}$ & 4 \\
\hline 551 & $31: 11$ & $50: 45$ & $08 / 03 / 69$ & 18 & 24.55 & 33.595 & Callinectes sapidus & 1 \\
\hline 552 & $31: 27$ & $50: 20$ & $08 / 03 / 69$ & 110 & 16.87 & 35.871 & $\begin{array}{l}\text { Moreiradromia antillensis, } \\
\text { Pseudorhombila octodentata }\end{array}$ & 2 \\
\hline 554 & $32: 12$ & $50: 12$ & $09 / 03 / 69$ & 149 & 16.94 & 35.875 & $\begin{array}{l}\text { Latreillia williamsi, Stenocionops } \\
\text { furcatus, Podochela atlantica }\end{array}$ & 3 \\
\hline 555 & $31: 55$ & $50: 39$ & $09 / 03 / 69$ & 89 & 18.02 & 35.989 & Arenaeus cribrarius & 1 \\
\hline 557 & $31: 56$ & $51: 40$ & $10 / 03 / 69$ & 19 & 24.34 & 32.926 & $\begin{array}{l}\text { Hepatus pudibundus, Callinectes } \\
\text { ornatus, Callinectes sapidus, } \\
\text { Persephona mediterranea }\end{array}$ & 4 \\
\hline 558 & $32: 11$ & $51: 16$ & $10 / 03 / 69$ & 54 & 18.85 & 34.588 & Libinia spinosa & 1 \\
\hline 559 & $32: 23$ & $50: 54$ & $10 / 03 / 69$ & 71 & 19.26 & 35.946 & Chasmocarcinus typicus & 1 \\
\hline 561 & $33: 14$ & $50: 42$ & $11 / 03 / 69$ & 128 & 16.05 & 35.729 & Acanthocarpus alexandri & 1 \\
\hline 564 & $32: 17$ & $52: 09$ & $11 / 03 / 69$ & 122 & 24.60 & 31.943 & $\begin{array}{l}\text { Hepatus pudibundus, Libinia } \\
\text { spinosa }\end{array}$ & 2 \\
\hline 565 & $32: 48$ & $52: 21$ & $12 / 03 / 69$ & 140 & 24.58 & 30.319 & $\begin{array}{l}\text { Callinectes sapidus, Arenaeus } \\
\text { cribrarius }\end{array}$ & 2 \\
\hline 566 & 33:05 & $51: 58$ & $12 / 03 / 69$ & 45 & 18.04 & 33.394 & Leurocyclus tuberculosus & 1 \\
\hline 568 & $33: 37$ & $51: 07$ & $12 / 03 / 69$ & 128 & 17.03 & 35.900 & $\begin{array}{l}\text { Latreillia williamsi, Spinolambrus } \\
\text { pourtalesii }\end{array}$ & 2 \\
\hline 569 & $34: 02$ & $51: 30$ & $12 / 03 / 69$ & 158 & 16.45 & 35.804 & $\begin{array}{l}\text { Osachila tuberosa, Latreillia } \\
\text { williamsi, Homola minima, Palicus } \\
\text { obesus, Palicus sica, Spinolambrus } \\
\text { pourtalesii, Portunus spinicarpus }\end{array}$ & 7 \\
\hline 571 & $33: 32$ & $52: 18$ & $13 / 03 / 69$ & 35 & 17.72 & 33.513 & $\begin{array}{l}\text { Leurocyclus tuberculosus, Ovalipes } \\
\text { trimaculatus }\end{array}$ & 2 \\
\hline 573 & $33: 41$ & $53: 08$ & $13 / 03 / 69$ & 19 & 24.28 & 32.539 & Hepatus pudibundus & 1 \\
\hline 576 & $34: 28$ & $51: 53$ & $14 / 03 / 69$ & 155 & 15.52 & 35.641 & $\begin{array}{l}\text { Latreillia williamsi, Podochela } \\
\text { atlantica }\end{array}$ & 2 \\
\hline 577 & $32: 20$ & $51: 54$ & $20 / 03 / 69$ & 24 & 23.09 & 33.061 & $\begin{array}{l}\text { Hepatus pudibundus, Libinia } \\
\text { spinosa, Portunus spinimanus }\end{array}$ & 3 \\
\hline 579 & $33: 15$ & $52: 14$ & $21 / 03 / 69$ & 36 & 21.73 & 32.853 & $\begin{array}{l}\text { Hepatus pudibundus, Persephona } \\
\text { mediterrânea, Spinolambrus } \\
\text { fraterculus, Portunus spinimanus, } \\
\text { Palicus obesus }\end{array}$ & 5 \\
\hline 581 & $32: 33$ & $51: 13$ & $22 / 03 / 69$ & 58 & 18.77 & 33.960 & Portunus spinicarpus & 1 \\
\hline
\end{tabular}


Table I. (cont.) Collection stations (coordinates, date, depth, temperature, salinity, species and number of species)

continuação

\begin{tabular}{|c|c|c|c|c|c|c|c|c|}
\hline 582 & $31: 59$ & $51: 01$ & $23 / 03 / 69$ & 58 & 22.20 & 33.907 & $\begin{array}{l}\text { Persephona mediterranea, } \\
\text { Pseudorhombila octodentata, } \\
\text { Libinia spinosa,Portunus } \\
\text { spinimanus, Leurocyclus } \\
\text { tuberculosus }\end{array}$ & 5 \\
\hline 583 & $31: 32$ & $50: 57$ & $23 / 03 / 69$ & 41 & 22.69 & 33.370 & $\begin{array}{l}\text { Hepatus pudibundus, Libinia } \\
\text { spinosa, Ovalipes trimaculatus }\end{array}$ & 3 \\
\hline 585 & $30: 38$ & $50: 02$ & $23 / 03 / 69$ & 55 & 22.17 & 34.976 & Portunus spinimanus & 1 \\
\hline 586 & $30: 08$ & $49: 49$ & $23 / 03 / 69$ & 44 & 22.36 & 35.332 & $\begin{array}{l}\text { Apiomithrax violaceus, Libinia } \\
\text { spinosa, Stenorhynchus seticornis }\end{array}$ & 3 \\
\hline 588 & $29: 20$ & $48: 57$ & $24 / 03 / 69$ & 78 & 20.69 & 35.906 & $\begin{array}{l}\text { Pseudorhombila octodentata, } \\
\text { Spinolambrus pourtalesii, Frevillea } \\
\text { hirsuta }\end{array}$ & 3 \\
\hline 590 & $28: 12$ & $48: 13$ & $25 / 03 / 69$ & 56 & 19.42 & 36.031 & $\begin{array}{l}\text { Hepatus pudibundus, Leurocyclus } \\
\text { tuberculosus, Portunus spinimanus }\end{array}$ & 3 \\
\hline 592 & $25: 20$ & $47: 18$ & $26 / 03 / 69$ & 51 & 18.77 & 35.718 & $\begin{array}{l}\text { Hepatus pudibundus, Persephona } \\
\text { mediterranea, Leurocyclus } \\
\text { tuberculosus, Portunus spinicarpus, }\end{array}$ & 4 \\
\hline \multicolumn{9}{|l|}{ GEDIP II } \\
\hline 1643 & $33: 46$ & $53: 17$ & $16 / 01 / 72$ & 15 & 22.20 & 31.865 & $\begin{array}{l}\text { Hepatus pudibundus, Libinia } \\
\text { spinosa, Ovalipes trimaculatus }\end{array}$ & 3 \\
\hline 1644 & $33: 58$ & $52: 51$ & $16 / 01 / 72$ & 294 & 19.02 & 32.575 & $\begin{array}{l}\text { Corystoides chilensis, Leurocyclus } \\
\text { tuberculosus, Libinia spinosa, } \\
\text { Ovalipes trimaculatus }\end{array}$ & 4 \\
\hline 1646 & $34: 25$ & $51: 49$ & $17 / 01 / 72$ & 166 & 14.38 & 35.454 & $\begin{array}{l}\text { Cymonomus quadratus, Deilocerus } \\
\text { perpusillus, Osachila tuberosa, } \\
\text { Latreillia williamsi, Euprognatha } \\
\text { rastellifera, Leurocyclus } \\
\text { tuberculosus, Palicus sica, } \\
\text { Spinolambrus fraterculus, Ovalipes } \\
\text { trimaculatus }\end{array}$ & 9 \\
\hline 1648 & $34: 06$ & $51: 33$ & $18 / 01 / 72$ & 180 & 14.47 & 35.584 & Latreillia williamsi, Palicus sica & 2 \\
\hline 1650 & $33: 40$ & $52: 22$ & $18 / 01 / 72$ & 35 & 17.82 & 32.669 & Ovalipes trimaculatus & 1 \\
\hline 1651 & $33: 22$ & $52: 47$ & $18 / 01 / 72$ & 140 & 24.32 & 31.955 & Libinia spinosa & 1 \\
\hline 1652 & $32: 58$ & $52: 27$ & $18 / 01 / 72$ & 122 & 24.92 & 32.689 & Libinia spinosa & 1 \\
\hline 1656 & $33: 17$ & $50: 34$ & $20 / 01 / 72$ & 173 & 15.83 & 35.804 & $\begin{array}{l}\text { Chasmocarcinus typicus, Myropsis } \\
\text { quinquespinosa, Latreillia williamsi, } \\
\text { Collodes rostratus, } \\
\text { Chasmocarcinus rathbuni, Palicus } \\
\text { sica }\end{array}$ & 6 \\
\hline 1659 & $32: 40$ & $51: 51$ & $20 / 01 / 72$ & 27 & 26.10 & 34.019 & $\begin{array}{l}\text { Leurocyclus tuberculosus, Ovalipes } \\
\text { trimaculatus }\end{array}$ & 2 \\
\hline 1660 & $32: 28$ & $52: 15$ & $20 / 01 / 72$ & 15 & 24.10 & 35.566 & $\begin{array}{l}\text { Hepatus pudibundus, Libinia } \\
\text { spinosa, }\end{array}$ & 2 \\
\hline 1661 & $32: 05$ & $51: 55$ & $20 / 01 / 72$ & 133 & 24.72 & 33.273 & Callinectes sapidus & 1 \\
\hline 1662 & $32: 20$ & $51: 22$ & $21 / 01 / 72$ & 52 & 19.45 & 35.900 & $\begin{array}{l}\text { Speocarcinus carolinensis, Libinia } \\
\text { spinosa, Callinectes sapidus, } \\
\text { Spinolambrus pourtalesii }\end{array}$ & 4 \\
\hline 1664 & $32: 46$ & $50: 25$ & $21 / 01 / 72$ & 200 & 16.85 & 35.808 & $\begin{array}{l}\text { Acanthocarpus alexandri, Portunus } \\
\text { spinicarpus }\end{array}$ & 2 \\
\hline 1666 & $32: 24$ & $50: 14$ & $22 / 01 / 72$ & 210 & 17.00 & 35.817 & Chasmocarcinus typicus & 1 \\
\hline 1667 & $32: 13$ & $50: 35$ & $22 / 01 / 72$ & 84 & 17.21 & 35.997 & Portunus spinicarpus & 1 \\
\hline 1668 & $32: 00$ & $50: 29$ & $22 / 01 / 72$ & 62 & 17.42 & 35.719 & Libinia spinosa & 1 \\
\hline 1669 & $31: 45$ & $51: 26$ & $22 / 01 / 72$ & 15 & 23.90 & 33.783 & Callinectes sapidus & 1 \\
\hline 1670 & $31: 30$ & $51: 00$ & $25 / 01 / 72$ & 22 & 24.09 & 34.860 & $\begin{array}{l}\text { Libinia spinosa, Ovalipes } \\
\text { trimaculatus. }\end{array}$ & 2 \\
\hline 1671 & $31: 40$ & $50: 40$ & $25 / 01 / 72$ & 80 & 16.91 & 35.794 & Arenaeus cribrarius & 1 \\
\hline
\end{tabular}


continuação

Table I. (cont.) Collection stations (coordinates, date, depth, temperature, salinity, species and number of species)

\begin{tabular}{|c|c|c|c|c|c|c|c|c|}
\hline 1674 & $31: 33$ & $49: 52$ & $25 / 01 / 72$ & 209 & 15.16 & 35.569 & $\begin{array}{l}\text { Palicus dentatus, Palicus alternatus, } \\
\text { Palicus sica }\end{array}$ & 3 \\
\hline 1675 & $31: 19$ & $50: 22$ & $26 / 01 / 72$ & 102 & 16.71 & 35.778 & $\begin{array}{l}\text { Chasmocarcinus typicus, Libidoclaea } \\
\text { granaria, Libinia spinosa, } \\
\text { Tetraxanthus rathbunae }\end{array}$ & 4 \\
\hline 1679 & $30: 53$ & $50: 16$ & $26 / 01 / 72$ & 60 & 16.89 & 35.745 & $\begin{array}{l}\text { Chasmocarcinus typicus, } \\
\text { Speocarcinus meloi, Libinia spinosa }\end{array}$ & 3 \\
\hline 1680 & $31: 03$ & 49:55 & $27 / 01 / 72$ & 130 & 16.43 & 35.775 & $\begin{array}{l}\text { Acanthocarpus alexandri, Myropsis } \\
\text { quinquespinosa }\end{array}$ & 2 \\
\hline 1686 & $30: 27$ & $49: 48$ & $28 / 01 / 72$ & 71 & 16.90 & 35.863 & Libinia spinosa & 1 \\
\hline 1687 & $30: 16$ & $50: 09$ & $28 / 01 / 72$ & 22 & 24.32 & 35.337 & Libinia spinosa, Ovalipes trimaculatus & 2 \\
\hline 1688 & $29: 43$ & 49:55 & $29 / 01 / 72$ & 24 & 24.29 & 35.681 & $\begin{array}{l}\text { Hepatus pudibundus, Persephona } \\
\text { mediterranea, Leurocyclus } \\
\text { tuberculosus, Libinia spinosa, } \\
\text { Portunus spinimanus }\end{array}$ & 5 \\
\hline 1691 & $30: 10$ & $48: 58$ & $29 / 01 / 72$ & 132 & 16.68 & 35.806 & $\begin{array}{l}\text { Acanthocarpus alexandri, } \\
\text { Chasmocarcinus typicus }\end{array}$ & 2 \\
\hline 1696 & $29: 39$ & $48: 41$ & $30 / 01 / 72$ & 124 & 15.66 & 35.670 & $\begin{array}{l}\text { Acanthocarpus alexandri, } \\
\text { Chasmocarcinus typicus, Portunus } \\
\text { spinicarpus }\end{array}$ & 3 \\
\hline 1697 & $29: 30$ & $48: 57$ & $20 / 01 / 72$ & 91 & 16.27 & 35.766 & $\begin{array}{l}\text { Acanthocarpus alexandri, } \\
\text { Chasmocarcinus typicus, } \\
\text { Speocarcinus meloi }\end{array}$ & 3 \\
\hline 1698 & 29:16 & $49: 14$ & $30 / 01 / 72$ & 51 & 16.96 & 35.500 & Libinia spinosa & 1 \\
\hline 1699 & $29: 13$ & 49:35 & $31 / 01 / 72$ & 200 & 24.01 & 35.725 & $\begin{array}{l}\text { Hepatus pudibundus, Persephona } \\
\text { mediterranea, Libinia spinosa, } \\
\text { Ovalipes trimaculatus }\end{array}$ & 4 \\
\hline 1700 & $28: 59$ & $48: 42$ & $31 / 01 / 72$ & 86 & 13.36 & 35.853 & Ovalipes trimaculatus & 1 \\
\hline 1703 & $28: 38$ & $47: 19$ & $01 / 02 / 72$ & 256 & 14.52 & 35.519 & Portunus spinicarpus & 1 \\
\hline 1706 & $29: 33$ & $48: 57$ & $06 / 04 / 72$ & 96 & 17.59 & 35.943 & Chasmocarcinus typicus & 1 \\
\hline 1711 & $30: 28$ & $48: 42$ & $07 / 04 / 72$ & 194 & 16.80 & 35.748 & Palicus alternatus & 1 \\
\hline 1712 & $30: 10$ & $49: 00$ & $08 / 04 / 72$ & 130 & 16.32 & 35.748 & $\begin{array}{l}\text { Chasmocarcinus typicus, Portunus } \\
\text { spinicarpus }\end{array}$ & 2 \\
\hline 1715 & $29: 43$ & 49:55 & $08 / 04 / 72$ & 24 & 23.03 & 35.081 & Persephona mediterranea & 1 \\
\hline 1718 & $30: 36$ & $49: 25$ & $09 / 04 / 72$ & 145 & 16.80 & 35.818 & $\begin{array}{l}\text { Acanthocarpus alexandri, } \\
\text { Chasmocarcinus typicus }\end{array}$ & 2 \\
\hline 1722 & $31: 02$ & $49: 52$ & $10 / 04 / 72$ & 135 & 16.99 & 35.850 & Portunus spinicarpus & 1 \\
\hline 1723 & $30: 55$ & $50: 11$ & $10 / 04 / 72$ & 90 & 16.79 & 35.788 & $\begin{array}{l}\text { Chasmocarcinus typicus, Portunus } \\
\text { spinicarpus, Chasmocarcinus } \\
\text { rathbuni }\end{array}$ & 3 \\
\hline 1724 & $30: 49$ & $50: 28$ & $10 / 04 / 72$ & 18 & 22.51 & 34.595 & Libinia spinosa & 1 \\
\hline 1725 & $31: 09$ & $50: 43$ & $11 / 04 / 72$ & 21 & 22.28 & 34.832 & $\begin{array}{l}\text { Hepatus pudibundus, Arenaeus } \\
\text { cribrarius }\end{array}$ & 2 \\
\hline 1730 & $31: 50$ & $50: 21$ & $12 / 04 / 72$ & 116 & 17.79 & 35.905 & Bellia picta & 1 \\
\hline 1732 & $31: 27$ & $51: 05$ & $12 / 04 / 72$ & 17 & 22.17 & 33.779 & Hepatus pudibundus & 1 \\
\hline 1740 & $34: 28$ & $51: 50$ & $19 / 04 / 72$ & 169 & 16.82 & 35.810 & $\begin{array}{l}\text { Osachila tuberosa, Latreillia williamsi, } \\
\text { Palicus sica }\end{array}$ & 3 \\
\hline 1742 & $34: 01$ & $51: 32$ & $19 / 04 / 72$ & 175 & 16.13 & 35.710 & Latreillia williamsi & 1 \\
\hline 1745 & $33: 21$ & $52: 49$ & $20 / 04 / 72$ & 13 & 20.05 & 33.127 & Leurocyclus tuberculosus & 1 \\
\hline 1748 & $33: 28$ & $51: 30$ & $20 / 04 / 72$ & 78 & 21.22 & 36.037 & Heterocrypta lapidea & 1 \\
\hline 1756 & $32: 22$ & $51: 20$ & $22 / 04 / 72$ & 57 & 19.78 & 33.257 & Heterocrypta lapidea & 1 \\
\hline 1758 & $32: 48$ & $50: 27$ & $22 / 04 / 72$ & 197 & 16.74 & 35.811 & $\begin{array}{l}\text { Acanthocarpus alexandri, } \\
\text { Chasmocarcinus typicus, Myropsis } \\
\text { quinquespinosa, Portunus spinicarpus }\end{array}$ & 4 \\
\hline
\end{tabular}


Table I. (cont.) Collection stations (coordinates, date, depth, temperature, salinity, species and number of species)

continuação

\begin{tabular}{|c|c|c|c|c|c|c|c|c|}
\hline 1848 & $30: 22$ & $48: 41$ & $03 / 08 / 72$ & 178 & 15.75 & 35.628 & Myropsis quinquespinosa & 1 \\
\hline 1851 & $29: 51$ & 49:37 & $04 / 08 / 72$ & 45 & 16.00 & 32.487 & Hepatus pudibundus & 1 \\
\hline 1853 & $30: 14$ & $50: 09$ & $05 / 08 / 72$ & 21 & 14.31 & 31.382 & Arenaeus cribrarius & 1 \\
\hline 1855 & $30: 37$ & 49:25 & $05 / 08 / 72$ & 150 & 16.22 & 35.696 & Myropsis quinquespinosa & 1 \\
\hline 1856 & $30: 42$ & 49:03 & $06 / 08 / 72$ & 192 & 15.80 & 35.648 & $\begin{array}{l}\text { Myropsis quinquespinosa, Latreillia } \\
\text { williamsi, Anomalothir furcillatus, } \\
\text { Euprognatha rastellifera, } \\
\text { Stenocionops spinosissimus, Palicus } \\
\text { sica }\end{array}$ & 6 \\
\hline 1859 & $31: 03$ & $49: 46$ & $06 / 08 / 72$ & 144 & 16.86 & 35.760 & Portunus spinicarpus & 1 \\
\hline 1860 & $30: 50$ & $50: 06$ & $06 / 08 / 72$ & 79 & 17.02 & 34.379 & Speocarcinus meloi & 1 \\
\hline 1867 & $35: 18$ & $54: 13$ & $11 / 08 / 72$ & 27 & 10.66 & 33.619 & Libinia spinosa, Ovalipes trimaculatus & 2 \\
\hline 1868 & $35: 33$ & $53: 48$ & $12 / 08 / 72$ & 58 & 10.02 & 33.695 & $\begin{array}{l}\text { Speocarcinus carolinensis, Collodes } \\
\text { rostratus, Leurocyclus tuberculosus, } \\
\text { Libinia spinosa, Rochinia gracilipes, } \\
\text { Ovalipes trimaculatus }\end{array}$ & 6 \\
\hline 1872 & $35: 15$ & $52: 33$ & $13 / 08 / 72$ & 170 & 12.16 & 35.106 & $\begin{array}{l}\text { Acanthocarpus alexandri, Myropsis } \\
\text { quinquespinosa,Homola mínima, } \\
\text { Mithrax besnardi }\end{array}$ & 4 \\
\hline 1873 & $35: 10$ & $52: 46$ & $13 / 08 / 72$ & 94 & 8.14 & 33.586 & Homola minima Eurypodius latreillei & 2 \\
\hline 1874 & $35: 00$ & 53:05 & $13 / 08 / 72$ & 48 & 10.36 & 33.629 & Rochinia gracilipes & 1 \\
\hline 1876 & $34: 35$ & $53: 58$ & $14 / 08 / 72$ & 22 & 10.86 & 33.257 & Libinia spinosa & 1 \\
\hline 1881 & $34: 45$ & $52: 05$ & $15 / 08 / 72$ & 179 & 10.49 & 34.857 & $\begin{array}{l}\text { Acanthocarpus alexandri, Lepteces } \\
\text { ornatus }\end{array}$ & 2 \\
\hline 1883 & $34: 27$ & $51: 50$ & $15 / 08 / 72$ & 175 & 13.45 & 35.331 & $\begin{array}{l}\text { Osachila antillensis, Latreillia } \\
\text { williamsi, Frevillea hirsuta, } \\
\text { Euprognatha rastellifera Palicus } \\
\text { dentatus, Palicus sica, Spinolambrus } \\
\text { fraterculus }\end{array}$ & 7 \\
\hline 1884 & $34: 15$ & $52: 12$ & $16 / 08 / 72$ & 64 & 10.56 & 34.054 & Rochinia gracilipes & 1 \\
\hline 1891 & 33:39 & $51: 07$ & $17 / 08 / 72$ & 200 & 11.78 & 35.076 & $\begin{array}{l}\text { Myropsis quinquespinosa, Portunus } \\
\text { spinicarpus }\end{array}$ & 2 \\
\hline 1893 & $33: 14$ & $51: 48$ & $18 / 08 / 72$ & 45 & 11.94 & 33.192 & Pelia rotunda, Libinia spinosa & 2 \\
\hline 1907 & $32: 07$ & $50: 40$ & $21 / 08 / 72$ & 91 & 18.34 & 35.976 & $\begin{array}{l}\text { Myropsis quinquespinosa, } \\
\text { Speocarcinus meloi, Portunus } \\
\text { spinicarpus, Chasmocarcinus } \\
\text { rathbuni }\end{array}$ & 4 \\
\hline 1909 & $31: 58$ & $50: 02$ & $21 / 08 / 72$ & 184 & 16.53 & 35.746 & Acanthocarpus alexandri & 1 \\
\hline 1916 & $35: 19$ & $54: 13$ & $29 / 10 / 72$ & 24 & 11.37 & 32.999 & Libinia spinosa, Ovalipes trimaculatus & 2 \\
\hline 1917 & $35: 30$ & $53: 46$ & $29 / 10 / 72$ & 52 & 9.95 & 33.564 & $\begin{array}{l}\text { Peltarion spinulosum, Libinia } \\
\text { ferreirae, Leurocyclus tuberculosus, } \\
\text { Uca maracoani, Ovalipes } \\
\text { trimaculatus, Callinectes ornatus }\end{array}$ & 6 \\
\hline 1918 & $35: 44$ & $53: 22$ & $30 / 10 / 72$ & 84 & 7.37 & 33.544 & $\begin{array}{l}\text { Peltarion spinulosum, Hepatus } \\
\text { pudibundus, Libidoclaea granaria }\end{array}$ & 3 \\
\hline 1919 & $35: 50$ & 53:06 & $30 / 10 / 72$ & 156 & 8.36 & 34.338 & Peltarion spinulosum & 1 \\
\hline 1921 & $35: 11$ & $52: 47$ & $30 / 10 / 72$ & 97 & 7.54 & 33.567 & Peltarion spinulosum & 1 \\
\hline 1923 & $34: 53$ & $53: 26$ & $30 / 10 / 72$ & 47 & 10.06 & 33.405 & $\begin{array}{l}\text { Leurocyclus tuberculosus, Libinia } \\
\text { spinosa, Ovalipes trimaculatus }\end{array}$ & 3 \\
\hline 1924 & $34: 34$ & $53: 56$ & $31 / 10 / 72$ & 22 & 13.26 & 32.122 & Ovalipes trimaculatus & 1 \\
\hline 1925 & 34:04 & $53: 29$ & $31 / 10 / 72$ & 20 & 12.35 & 31.669 & Libinia spinosa. & 1 \\
\hline 1926 & $34: 14$ & $53: 08$ & $31 / 10 / 72$ & 29 & 10.50 & 32.826 & Libinia spinosa & 1 \\
\hline 1931 & 33:47 & $53: 16$ & $01 / 11 / 72$ & 19 & 13.95 & 30.845 & Libinia spinosa & 1 \\
\hline 1932 & $33: 21$ & $52: 48$ & $01 / 11 / 72$ & 14 & 14.25 & 30.720 & Libinia spinosa & 1 \\
\hline 1937 & $32: 58$ & $52: 30$ & $02 / 11 / 72$ & 13 & 14.37 & 30.691 & Libinia spinosa & 1 \\
\hline 1938 & $32: 28$ & $52: 14$ & $02 / 11 / 72$ & 15 & 15.89 & 30.304 & Libinia spinosa & 1 \\
\hline 1940 & $32: 51$ & $51: 26$ & $02 / 11 / 72$ & 59 & 10.96 & 33.099 & Libinia spinosa, Portunus spinicarpus & 2 \\
\hline
\end{tabular}

Recebido: 08/06/2009

Aceito:13/08/2009 
